\title{
Fine-root production in two secondary forest sites with distinct ages in Eastern Amazon
}

\author{
Tâmara Thaiz Santana LIMA¹, Izildinha Souza MIRANDA², Steel Silva VASCONCELOS ${ }^{3}$
}

\begin{abstract}
The objective of this work was to assess the fine-root ( $\leq 2 \mathrm{~mm}$ diameter) production dynamics of two forest regrowths at different ages. Fine-root production was monitored by the ingrowth core method in one 18-year-old site ( 2 ha) and one 10-year-old site ( 0.5 ha), both localized in the Apeú region, Northern Pará State, Brazil. The sites were abandoned after successive shifting cultivation, beginning in 1940. Monthly production of live fine-root was similar between sites and was influenced by rainfall seasonality, with higher production during the dry season than the wet season for mass and length. However, mortality in terms of mass was higher in the 10-year-old site than in the 18-year-old site. The seasonality influenced mortality only in the 18 -year old site following the pattern observed for live fine-root. The influence seasonal on mortality in terms of length was different between sites, with higher mortality during the wet season in the 10-year-old site and higher mortality during the dry season in the 18-year-old site. Specific root length was higher during the wet season and at the 10-year-old site. Fine-root production was not influenced by the chronosequence of the sites studied, probably fine-root production may have already stabilized in the sites or it depended more on climate and soil conditions. The production of fine-roots mass and length were indicators that generally showed the same pattern.
\end{abstract}

KEYWORDS: drought, root biomass, seasonality, succession, tropical forest

\section{Produção de raízes finas em dois sítios de floresta secundária com diferentes idades na Amazônia Oriental}

\section{RESUMO}

O objetivo deste trabalho foi avaliar a dinâmica de produção de raízes finas (diâmetro $\leq 2 \mathrm{~mm}$ ) em duas áreas de floresta secundária com diferentes idades. A produção de raízes finas foi monitorada utilizando a técnica de ingrowth core em um sítio com 18 anos de idade ( 2 ha) e um outro sítio com 10 anos de idade ( 0,5 ha), localizados na regiáo de Apeú, nordeste do Estado do Pará. Os sítios foram abandonados depois de sucessivos ciclos agrícolas, iniciados em 1940. A produção mensal de raízes vivas foi semelhante entre os sítios e influenciada pela sazonalidade pluviométrica, com maior produção durante a estação seca para massa e comprimento. No entanto, a mortalidade, em termos de massa, foi maior no sítio de 10 anos. A sazonalidade influenciou a mortalidade somente no sítio de 18 anos, seguindo o padrão observado para as raízes vivas. A influência sazonal sobre a mortalidade em termos de comprimento foi diferente entre os sítios, com maior mortalidade durante a estação chuvosa no sítio de 10 anos e maior mortalidade durante a estação seca no sítio de 18 anos. O comprimento radicular específico foi maior durante a estação chuvosa e influenciado pelos sítios, sendo maior no sítio de 10 anos. A produção de raízes finas não foi influenciada pela cronossequência dos sítios estudados, provavelmente porque a produçáo de raízes finas pode ter estabilizado nos sítios ou depende mais das condiçóes de clima e solo. A produção, em termos de massa e comprimento, foram indicadores que geralmente mostraram o mesmo padrão.

PALAVRAS-CHAVE: biomassa, floresta tropical, sazonalidade, seca, sucessão

1 Universidade Federal Rural da Amazônia - UFRA/Campus Paragominas. thaillima@hotmail.com

2 Universidade Federal Rural da Amazônia - UFRA/Campus Belém. izildinha.miranda@ufra.edu.br

${ }^{3}$ EMBRAPA-Amazônia Oriental. steel@cpatu.embrapa.br 


\section{INTRODUCTION}

In tropical secondary forests of the Amazon, studies have concentrated on describing patterns of succession (Tucker et al. 1998; Lu et al. 2003; Smith et al. 2003; Vieira et al. 2003; Araújo et al. 2005), natural regeneration (Vieira and Hosokawa 1989; Lima Filho et al. 2002), floristic and structural composition (Steininger 2000; Coelho et al. 2003; Lima et al. 2007; Rodrigues et al. 2007a) and plant biomass accumulation above ground (Nelson et al. 1999; Steininger 2000; Feldpausch et al. 2004; Lima et al. 2007; Rodrigues et al. 2007b). Most published studies on secondary forest development in the Amazon have been carried out starting from successional chronosequences represented by a series of sites of different ages, but with similar edaphoclimatic characteristics and soil-use history (Araújo et al. 2005).

Tropical secondary forests usually have rapid rates of above-ground production, especially during the initial stages of succession (Hughes et al. 1999). Above ground carbon accumulation is rapid in these forests but below-ground gains represent the compartment with largest potential for continuous carbon accumulation (Feldpausch et al. 2004).

Fine root dynamics contribute significantly to the biogeochemical cycling in forest ecosystems, including the production and emission of greenhouse gases (Silver et al. 2005), and in addition the fine roots tend to be more dynamic than coarse roots because fine roots have a higher growth rate (Eissenstat et al. 2000). In spite of the importance of fine roots in face of global changes, few studies have been carried out on this compartment of vegetation compared to the components above ground, which may be due to the difficulty of measuring fine-root production. According to Jordan and Escalante (1980) and Norby et al. (2004) fine-root production is one of the parameters that is most difficult to measure, which limits the capacity to predict the effects of environmental change on root dynamics (Eissenstat et al. 2000).

Several environmental factors affect fine root production (Hendrick and Pregitzer 1996; Silver et al. 2005), such as seasonality (Cavelier et al. 1999; Yavitt and Wright 2001; Lima et al. 2010), soil nutrients (Maycock and Congdon 2000; Stewart 2000; Blair and Perfecto 2001) soil temperature and moisture (McGroddy and Silver 2000; Metcalfe et al. 2008). Floristic composition (Visalakshi 1994), forest successional stage and soil-use history (Castellanos et al. 2001; Cavelier et al. 1996; Jaramillo et al. 2003) have also been reported as sources of variation for fine-root production. The objective of this study was to assess the fine root production dynamics in two tropical forest regrowth sites with distinct ages.

\section{MATERIALS AND METHODS}

\section{Study area}

The experiment was carried out in forest regrowth, located in the Experimental Station of the Federal Rural University of the Amazon (1017'53” S, 47056'56” W), of Apeú region, Northern Pará State, Brazil. The regional landscape consists of a mosaic of secondary forests at different successional stages, surrounded by highways, plantations, and cattle pastures (Vieira et al. 2007). Approximately 50\% of this region was covered by secondary forest at different successional stages at the start of the past century and $22 \%$ were less than 6 years old (Vieira et al. 2003).

In the present study, two sites of different ages were selected in 2005: one 10-year-old site (FS10) with an area of approximately 0.5 ha and an 18-year-old site (FS18) with an area of approximately 2 ha. The sites were abandoned after multiple cycles of shifting cultivation, beginning in the 1940s; each cycle included 1-2 years of Zea mays L. (corn), Manihot esculenta Crantz (cassava) and Vigna unguiculata (L.) Walp (cowpea) cultivation followed by fallow (G. Silva e Souza \& O.L. Oliveira pers. comm.). The 10-year-old site was abandoned in 1995 and is surrounded by forests of different successional stages and the 18-year-old site was abandoned in 1987 and is adjacent to a riparian forest on one side and secondary forest on the other sides. The two sites were separated by a 7-m-wide road (Araújo et al. 2005).

The relief is gently rolling. The soils are classified as Dystrophic Yellow Latosol Stony Phase I (Concrecionary, Lateritic), corresponding to Sombriustox in U.S. Soil Taxonomy. The soils are well-drained with a low natural fertility and slight laminar erosion (Tenório et al. 1999). The climate, according to the Köppen classification, is the Am3 type. Mean annual temperature ranges from $24.7^{\circ} \mathrm{C}$ to 27.3 ${ }^{\circ} \mathrm{C}$ and mean annual relative air humidity ranges from $78 \%$ to $90 \%$ (Martorano and Pereira 1993). From 2005 to 2007 mean annual rainfall was $2842 \mathrm{~mm}$ and approximately $80 \%$ of the rainfall occurred between January and July. During the dry season (August-December), the mean monthly rainfall was approximately $123 \mathrm{~mm}$, whereas in the wet season (January to July), mean monthly rainfall was approximately $318 \mathrm{~mm}$ (Figure 1). To define the dry and wet seasons was used rainfall and soil water potential data (Vasconcelos et al. 2004).

In 2005 mean stem density for trees with diameter at breast height $(\mathrm{dbh}) \geq 1 \mathrm{~cm}$ in the 10 -year-old site was 2.8 \pm 1.9 (SE) individuals $\mathrm{m}^{-2}$ and mean basal area was $8.1 \pm$ $1.5 \mathrm{~m}^{2} \mathrm{ha}^{-1}$. In the same site the five most abundant plant species $(\mathrm{dbh} \geq 1 \mathrm{~cm})$ were Lacistema pubescens Mart., Vismia 


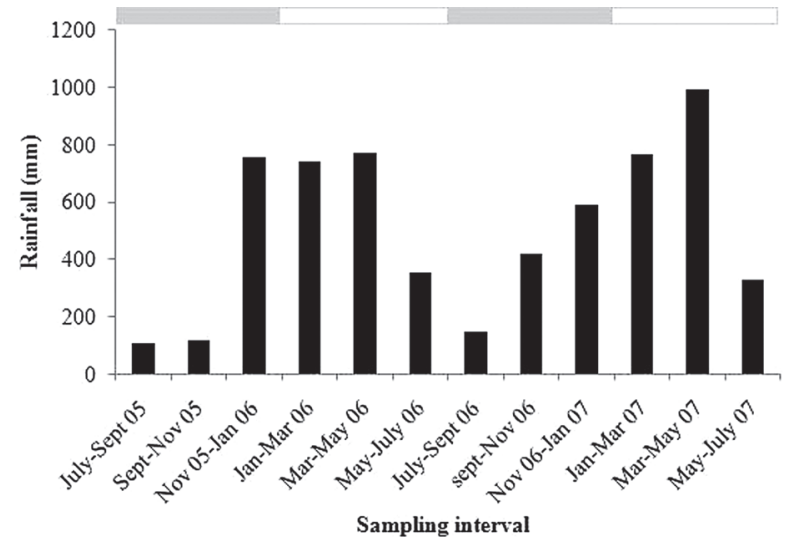

Figure 1 - Accumulated rainfall according to sampling intervals between January 2005 and July 2007 in the Experimental Station of the Federal Rural University of the Amazonia, in the northeast of the state of Pará, Brazil. Gray and white horizontal bars indicate dry and wet seasons, respectively.

guianensis (Aubl.) Choisy, Myrcia sylvatica (G. Mey.) DC., Banara guianensis Aubl. and Rollinia exsucca (DC. ex Dunal) A. DC. In the 18 -year-old site, mean stem density was $1.5 \pm$ 2.0 individuals $\mathrm{m}^{-2}$ and the basal area was $28.4 \pm 9.2 \mathrm{~m}^{2} \mathrm{ha}^{-1}$. The five most abundant species ( $\mathrm{dbh} \geq 1 \mathrm{~cm}$ ) were Lacistema pubescens Mart., Myrcia sylvatica (G. Mey.) DC., Cupania scrobiculata Rich., Lacistema aggregatum Berg Rusby and Inga rubiginosa (Rich.) DC.

\section{Measuring fine-root production}

Four $20 \mathrm{~m}$ x $20 \mathrm{~m}$ plots were set up randomly in each site. Because we sampled two sites only, it makes difficult to generalized our findings to other second regrowths areas of the same situation. Fine root growth was assessed by the ingrowth core method (Cuevas and Medina 1988; Kavanagh and Kellman 1992; Makkonen and Helmisaari 1999), which is indicated to compare root growth in different environments (Vogt et al. 1998; Makkonen and Helmisaari 1999). Root ingrowth cores were cylindrical bags (height $=10 \mathrm{~cm}$ and diameter $=5 \mathrm{~cm}$ ) of high-density polyethylene, $2-\mathrm{mm}$ mesh size, filled with root-free superficial soil $(0-10 \mathrm{~cm})$, excluding the litter, collected from an area adjacent to the experimental site, previously air-dried, and sieved under a 2-mm mesh. Roots were removed through sieving and picking with forceps.

In July 2005, five cores were randomly buried in each plot at a depth of 0 to $10 \mathrm{~cm}$ and retrieved two months later, when they were replaced by another set of five cores with new root-free superficial soil. Root core replacement was carried out until July 2007, resulting in 12 sampling dates, five cores per plot.

Samples were transported in refrigerated polystyrene containers to the Federal Rural University of Amazonia at
Belém, about $60 \mathrm{~km}$ from the experimental site. Collected samples were kept under refrigeration $\left(4^{\circ} \mathrm{C}\right)$ for a maximum period of 3 months for conserve the characteristics morphological and structural until processed at laboratory. Samples were soaked in plastic trays containing tap water for separation of live and dead fine roots $(\leq 2 \mathrm{~mm})$ based on characteristics of elasticity and color; live roots usually were light-colored and elastic, while dead roots usually were darkcolored and brittle (Gower 1987; Kavanagh and Kellman 1992; Makkonen and Helmisaari 1999; McClaugherty et al. 1982; Yavitt and Wright 2001). Live and dead roots were stored separately at $4{ }^{\circ} \mathrm{C}$ in plastic flasks with a solution of commercial alcohol at $50 \%$ for 4 months at most. Roots were stained with a solution of gentian violet $(200 \mathrm{ml}$ tap water + 10 drops of gentian violet) for $24 \mathrm{~h}$, put on an acetate sheet so that root overlapping was avoided, and scanned with an HP Scanjet 4670 (600 dpi). Total length of scanned images was calculated with the SIARCS 3.0 (Sistema Integrado de Análise de Raízes e Cobertura do Solo - Integrated Analysis System of Roots and Soil Cover) software developed by the Brazilian Enterprise for Agricultural Research - Embrapa (Jorge 1996; Jorge and Crestana 1996). After the image capture process, roots were dried at $75^{\circ} \mathrm{C}$ for $24 \mathrm{~h}$ and weighed to the nearest $0.0001 \mathrm{~g}$.

Fine root production in the surface $10 \mathrm{~cm}$ soil layer was expressed in terms of mass $\left(\mathrm{g} \mathrm{m}^{-2} \mathrm{month}^{-1}\right)$ and length $\left(\mathrm{m} \mathrm{m}^{-2}\right.$ month $^{-1}$ ) by dividing weight and length by the area of the ingrowth core base, respectively, and by measurement interval (Lima et al. 2010). We averaged the five samples per plot, resulting in $n=4$ for each site and sampling date. Specific root length (SRL) (Jackson et al. 1997; Metcalfe et al. 2008) was calculated by dividing live root length by live root biomass and represented an index of fine root morphology.

\section{Statistical analysis}

The effects of sites, collection period and site-by-collection period interaction on fine-root mass and length were analyzed using a repeated measures analysis of variance. Multiple comparison of means was performed with Tukey's test at 5\%. When necessary, we performed $\ln$ transformations to meet the model assumptions of normality, based on the criteria of $\mathrm{P}>$ 0.05 in the Shapiro-Wilk test. Means and standard errors were calculated on the basis of untransformed data. The analyses were performed with the SYSTAT 11.0 statistical program.

\section{RESULTS}

\section{Fine-root mass}

Annual mass production of live fine roots was not significantly affected by site, collection period and sitecollection period interaction (Table 1), whereas mass growth 
of dead fine roots was significantly higher in the 10-year-old site $\left(2.24 \pm 1.24 \mathrm{~g} \mathrm{~m}^{-2} \mathrm{y}^{-1}\right)$ than in the 18 -year-old site (1.67 $\left.\pm 0.38 \mathrm{~g} \mathrm{~m}^{-2} \mathrm{y}^{-1}\right)$.

Monthly production of live fine-root mass was not significantly different (Table 1$)$ between the sites (FS10 $=$ $\left.14.73 \pm 1.15 \mathrm{~g} \mathrm{~m}^{-2} \mathrm{mo}^{-}{ }^{-} ; \mathrm{FS} 18=14.34 \pm 1.83 \mathrm{~g} \mathrm{~m}^{-2} \mathrm{mo}^{-1}\right)$. However, the monthly production of live fine-root mass was seasonal (Figure $2 \mathrm{a}$ ) and significantly $(\mathrm{P}<0.0001)$ higher in the dry season than in the wet season for both sites (FS10: dry season $=17.52 \pm 1.27 \mathrm{~g} \mathrm{~m}^{-2} \mathrm{mo}^{-1}$, wet season $=11.94$ $\pm 1.06 \mathrm{~g} \mathrm{~m}^{-2} \mathrm{mo}^{-1}$; FS18: dry season $=17.92 \pm 2.93 \mathrm{~g} \mathrm{~m}^{-2}$ mo- ${ }^{1}$, wet season $\left.=10.76 \pm 1.05 \mathrm{~g} \mathrm{~m}^{-2} \mathrm{mo}^{-1}\right)$.

Monthly dead fine-root mass production was significantly higher (Table 1) for the 10-year-old site $\left(0.37 \pm 0.08 \mathrm{~g} \mathrm{~m}^{2}\right.$ $\left.\mathrm{mo}^{-1}\right)$ than in the 18 -year-old site $\left(0.28 \pm 0.06 \mathrm{~g} \mathrm{~m}^{-2} \mathrm{mo}^{-1}\right)$. Seasonality of root mortality occurred only in the 18 -year-old site $(\mathrm{P}<0.05)$ with higher mortality in the dry season than in the wet season (dry season $=0.38 \pm 0.09 \mathrm{~g} \mathrm{~m}^{-2} \mathrm{mo}^{-1}$, wet season $=0.18 \pm 0.07 \mathrm{~g} \mathrm{~m}^{-2} \mathrm{mo}^{-1}$; Figure $2 \mathrm{~b}$ ).

\section{Fine-root length}

Annual length production of live fine-root was significantly affected by collection period only (Table 1), with significantly $(\mathrm{P}<0.0001)$ higher production in the second year interval $\left(\right.$ FS10 $=5470.4 \pm 131.92 \mathrm{~m} \mathrm{~m}^{-2} \mathrm{y}^{-1} ; \mathrm{FS} 18=4860.0 \pm 171.09$ $\mathrm{m} \mathrm{m}^{-2} \mathrm{y}^{-1}$ ) than in the first year interval (FS10 $=4392.2 \pm$ $56.08 \mathrm{~m} \mathrm{~m}^{-2} \mathrm{y}^{-1}$; FS18 $\left.=3367.2 \pm 93.94 \mathrm{~m} \mathrm{~m}^{-2} \mathrm{y}^{-1}\right)$ for both the sites. Mortality was significantly higher (Table 1) in the 10 -year-old site $\left(79.63 \pm 40.85 \mathrm{~m} \mathrm{~m}^{-2} \mathrm{y}^{-1}\right)$ than in the 18-year-old site $\left(68.00 \pm 23.07 \mathrm{~m} \mathrm{~m}^{-2} \mathrm{y}^{-1}\right)$.

There was no significant difference in the monthly production of live and dead fine-root length between the two sites (Table 1). There was an effect only of collection

Table 1 - $F$ statistics and associated significance levels for the effect of sites (10-year-old and 18-year-old), collection period (dry and wet seasons) and their interaction on fine root production in the surface $10 \mathrm{~cm}$ soil layer in a tropical regrowth forest stand in eastern Amazonia ${ }^{\mathrm{a}}$

\begin{tabular}{lccc}
\hline Variable & Site & $\begin{array}{c}\text { Collection } \\
\text { Period }\end{array}$ & $\begin{array}{c}\text { Site } x \text { Collection } \\
\text { Period }\end{array}$ \\
\hline Monthly live root mass & $0.09 \mathrm{~ns}$ & $4.38^{\star * \star}$ & $0.86 \mathrm{~ns}$ \\
Monthly dead root mass & $9.87^{\star}$ & $5.63^{\star * \star}$ & $1.19 \mathrm{~ns}$ \\
Monthly live root length & $1.28 \mathrm{~ns}$ & $6.39^{\star * *}$ & $0.55 \mathrm{~ns}$ \\
Monthly dead root length & $1.25 \mathrm{~ns}$ & $7.32^{\star * *}$ & $3.87 \mathrm{~ns}$ \\
Monthly SRL & $9.68^{*}$ & $3.03^{\star *}$ & $1.24 \mathrm{~ns}$ \\
Annual live root mass & $0.001 \mathrm{~ns}$ & $0.09 \mathrm{~ns}$ & $0.93 \mathrm{~ns}$ \\
Annual dead root mass & $8.63^{*}$ & $1.5 \mathrm{~ns}$ & $3.47 \mathrm{~ns}$ \\
Annual live root length & $0.83 \mathrm{~ns}$ & $6.61^{*}$ & $0.17 \mathrm{~ns}$ \\
Annual dead root length & $18.39^{\star *}$ & $0.45 \mathrm{~ns}$ & $1.05 \mathrm{~ns}$
\end{tabular}

aThe level of significance is indicated ${ }^{*}: \mathrm{P}<0.05,{ }^{* *}: \mathrm{P}<0.01,{ }^{* * *}: \mathrm{P}<0.001$, ns: not significant.

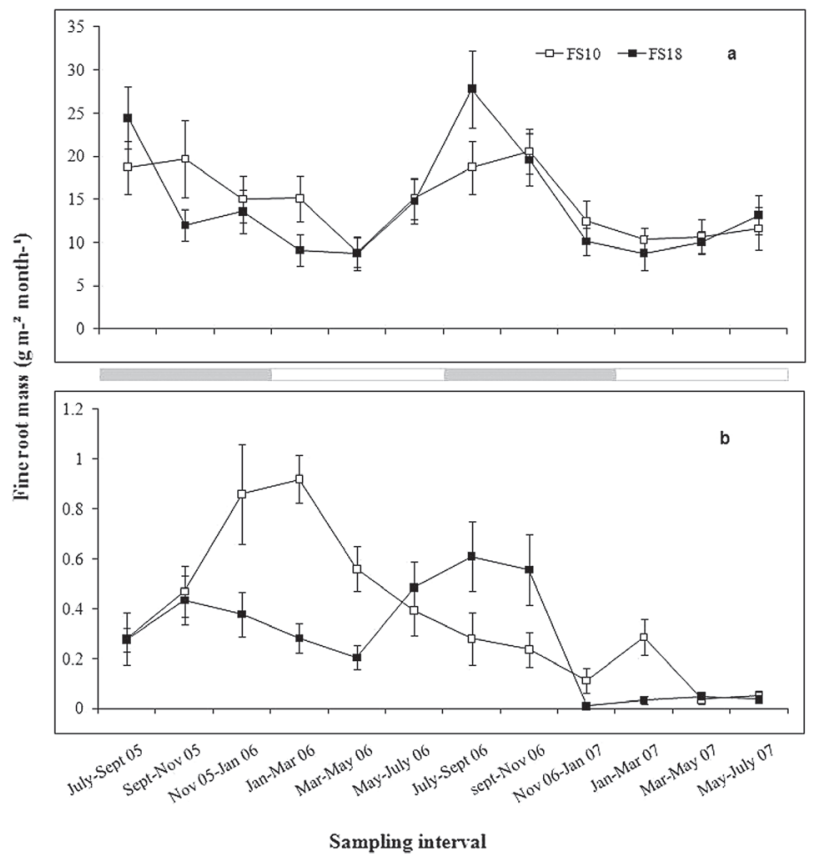

Figure 2 - Production of live (a) and dead (b) fine root mass in 10-yearold (FS10) and 18-year-old (FS18) sites from July 2005 to July 2007 in a secondary forest in the Eastern Amazonia. Results are mean \pm standard error $(n=4)$. Gray and white horizontal bars mark dry and wet seasons, respectively.

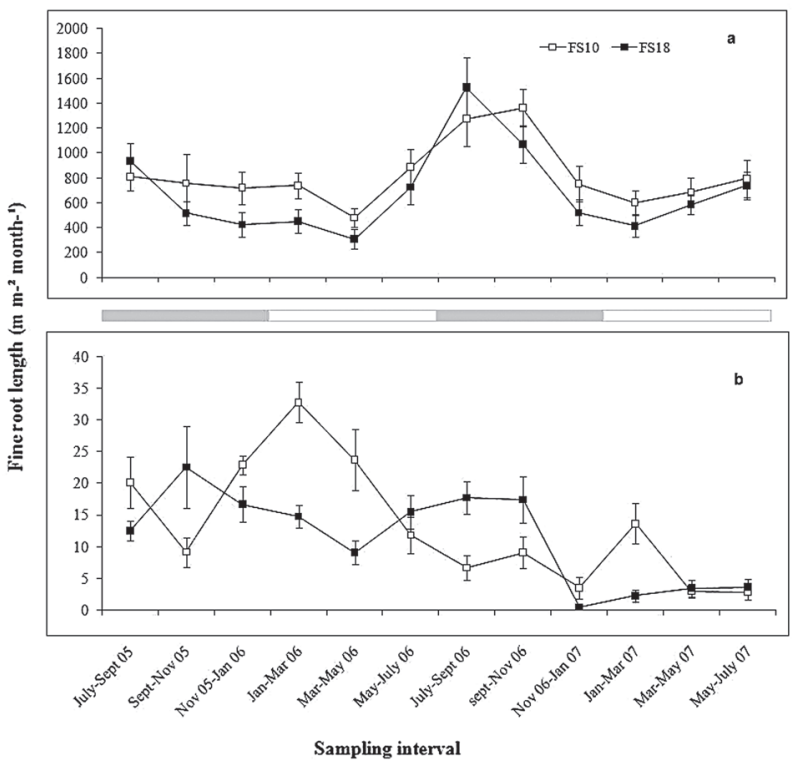

Figure 3 - Production of live (a) and dead (b) fine root length in 10-yearold (FS10) and 18-year-old (FS18) sites from July 2005 to July 2007 in a secondary forest in the Eastern Amazonia. Results are mean \pm standard error $(n=4)$. Gray and white horizontal bars mark dry and wet seasons, respectively. 
period for monthly production of live fine-root length; the seasonal effect can be observed in the Figure 3a with higher production in the dry season $\left(\mathrm{FS} 10=946.03 \pm 119.03 \mathrm{~m} \mathrm{~m}^{-2}\right.$ $\mathrm{mo}^{-1}$; FS18 $\left.=833.28 \pm 174.53 \mathrm{~m} \mathrm{~m}^{-2} \mathrm{mo}^{-1}\right)$ than in the wet season $\left(\mathrm{FS} 10=697.75 \pm 58.68 \mathrm{~m} \mathrm{~m}^{-2} \mathrm{mo}^{-1}\right.$; FS18 $=537.93$ $\left.\pm 71.43 \mathrm{~m} \mathrm{~m}^{-2} \mathrm{mo}^{-1}\right)$.

For production of dead fine-root length there was a significant effect collection period (Table 1). Production of dead fine-root length was significantly higher in the dry season than in the wet season at the 18-y-old site (dry season $=14.55$ $\pm 3.11 \mathrm{~m} \mathrm{~m}^{-2} \mathrm{mo}^{-1}$, wet season $=8.12 \pm 2.42 \mathrm{~m} \mathrm{~m}^{-2} \mathrm{mo}^{-1}$; Figure $3 \mathrm{~b}$ ). During dry season the 10-year-old site showed slightly, but significantly lower mortality than during the wet season $\left(\right.$ dry season $=11.92 \pm 3.17 \mathrm{~m} \mathrm{~m}^{-2} \mathrm{mo}^{-1}$, wet season $=$ $14.63 \pm 4.81 \mathrm{~m} \mathrm{~m}^{-2} \mathrm{mo}^{-1}$; Figure $3 \mathrm{~b}$ ).

\section{Fine-root morphology}

The SRL was significantly different between sites (Table 1) and was greater at the 10 -year-old site than at the 18 -year-old site $\left(F S 10=65.36 \pm 3.88 \mathrm{~m} \mathrm{~g}^{-1} ;\right.$ FS18 $=52.74 \pm 3.74 \mathrm{~m} \mathrm{~g}^{-1}$; Figure 4). At the 18 -year-old site the SRL was highly seasonal (Table 1), being higher in the wet season than in the dry season (FS18: dry season $=47.88 \pm 3.64 \mathrm{~m} \mathrm{~g}^{-1}$, wet season $=57.60 \pm$ $5.96 \mathrm{~m} \mathrm{~g}^{-1}$ ). At the 10 -year-old site the SRL was slightly, but significantly, lower in the dry season than in the wet season (FS10: dry season $=64.57 \pm 7.13 \mathrm{~m} \mathrm{~g}^{-1}$, wet season $=66.74$ $\pm 3.91 \mathrm{~m} \mathrm{~g}-^{1}$; Figure 4).

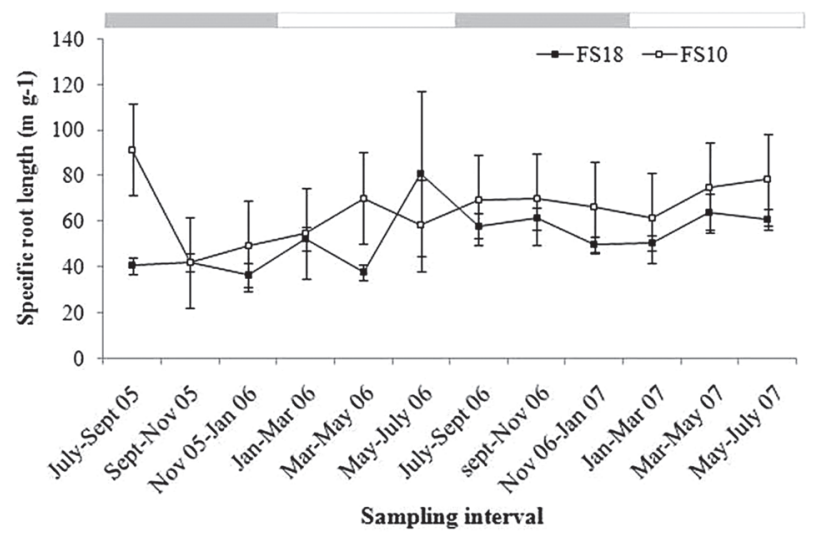

Figure 4 - Specific length of live fine root in 10-year-old (FS10) and 18-yearold (FS18) sites from July 2005 to July 2007 in a secondary forest in the Eastern Amazonia. Results are mean \pm standard error $(n=4)$. Gray and white horizontal bars mark dry and wet seasons, respectively.

\section{DISCUSSION}

The annual production values of fine-root biomass in this study were lower than those reported in other studies using the ingrowth core method in tropical forests (Table 2). The annual fine-root biomass production at the FS10 and FS18 sites was comparable to the production in one of the clearings $\left(126 \mathrm{~m}^{2}\right)$ reported by Sanford (1990); therefore, the biomass production values reported in this study for the FS10 and FS18 may be in line with the reality of the succesional stages of these sites.

The similarity detected between the two study sites concerning live and dead fine root production may have been related to the floristic similarities between the sites and the soil use history, as reported by Coelho et al. (2003) and Araújo et al. (2005). Furthermore, the two sites were only 7 $\mathrm{m}$ apart and therefore subject to the same climatic variation and soil type. According to Cairns et al. (1997) and Vogt et al. (1996) the pattern of root biomass allocation in a forest ecosystem depends mainly on soil and climate characteristics.

Similarity of fine root biomass between forests of different ages has been reported previously for other tropical regions. Cavelier et al. (1996) found no difference in root biomass between 10- and 20-year-old secondary forests in Colombia. In a tropical forest in Mexico, Jaramillo et al. (2003) observed a lower root biomass in young secondary forests compared to the primary forest, but the authors did not find any significant difference between root biomass of two 8- and 20-year-old secondary forests.

Live fine-root production in terms of mass and length was markedly seasonal and was greater in the early dry than in the wet season. Variation in root production associated with rainfall seasonality was also observed in other studies in tropical forests (Kavanagh and Kellman 1992; Visalakshi 1994; Sundarapandian and Swamy 1996; Cavelier et al. 1999; Metcalfe et al. 2008; Lima et al. 2010), but there was greater fine-root production in the wet compared to the dry season in these studies.

The seasonal pattern of production and root length may be related to changes in organic matter accumulation (Cuevas and Medina 1988; Aerts et al. 1992; Sundarapandian and Swany 1996), nutrient concentration in the soil (Maycock and Congdon 2000; Pregitzer et al. 2000; Stewart 2000; Blair and Perfecto 2001), soil moisture (Hook et al. 1994; Visalakshi 1994; Makkonen and Helmisaari 1999) and microbial activity (Zangaro et al. 2007).

Higher litterfall rates occurred during the dry season for the 18-y-old site (Vasconcelos et al. 2008), coinciding with the greater fine-root production. According to Sundarapandian and Swamy (1996), fine-root production can increase significantly with litter accumulation.

At the 18-year-old site, the soil microbial biomass mineralized more nitrogen during the wet than during the dry season (Rangel Vasconcelos et al. 2005). Thus fine-root production may be limited in the wet season due to high soil nitrogen concentrations (Valverde-Barrantes et al. 2007). 
The existence of negative correlation between nitrogen concentration and fine-root biomass has been reported for other sites in mature tropical forests (Gower and Vitousek 1989; Maycock and Congdon 2000). Less information is available for the 10-year-old site that limited detailed comparisons.

The greater root length during the dry season may have been related to the need for the plants to acquire water and nutrients. Soil water availability is probably the most important factor that accounts for changes in fine-root production strategies (Dowdy et al. 1995; Kätterer et al. 1995). According to Joslin et al. (2000), some species respond to drought by increasing root length, resulting in increased root:shoot ratio. This strategy may explain the live fine-root production peaks detected in the dry months in the present study.

Table 2 - Fine root production in tropical forests ${ }^{\mathrm{a}}$

\begin{tabular}{|c|c|c|c|c|c|c|}
\hline Forest type & Location & $\begin{array}{c}\text { Diameter } \\
\text { class } \\
(\mathrm{mm})\end{array}$ & Methodology & $\begin{array}{l}\text { Sampling } \\
\text { depth } \\
(\mathrm{cm})\end{array}$ & $\begin{array}{c}\text { Fine root } \\
\text { production } \\
\left(\mathrm{g} \mathrm{m}^{-2} \text { year }^{-1}\right)\end{array}$ & Source \\
\hline Amazonian Tropical Forest & San Carlos, Venezuela & $\leq 2$ & Ingrowth core & 10 & 806 & Cuevas and Medina (1988) \\
\hline $\begin{array}{l}\text { Amazonian Tropical Forest } \\
\text { (sandy soil) }\end{array}$ & $\begin{array}{c}\text { Floresta Nacional de Caxiuanã, } \\
\text { Pará, Brazil }\end{array}$ & $\leq 2$ & Ingrowth core & 30 & 400 & Metcalfe et al. (2008) \\
\hline $\begin{array}{l}\text { Amazonian Tropical Forest } \\
\text { (clay soil) }\end{array}$ & $\begin{array}{c}\text { Floresta Nacional de Caxiuanã, } \\
\text { Pará, Brazil }\end{array}$ & $\leq 2$ & Ingrowth core & 30 & 400 & Metcalfe et al. (2008) \\
\hline $\begin{array}{l}\text { Amazonian Tropical Forest } \\
\text { (dry plot) }\end{array}$ & $\begin{array}{l}\text { Floresta Nacional de Caxiuanã, } \\
\text { Pará, Brazil }\end{array}$ & $\leq 2$ & Ingrowth core & 30 & 300 & Metcalfe et al. (2008) \\
\hline $\begin{array}{l}\text { Amazonian Tropical Forest } \\
\text { (fertile plot) }\end{array}$ & $\begin{array}{c}\text { Floresta Nacional de Caxiuanã, } \\
\text { Pará, Brazil }\end{array}$ & $\leq 2$ & Ingrowth core & 30 & 700 & Metcalfe et al. (2008) \\
\hline Amazonian Tropical Forest & San Carlos, Venezuela & $<2$ & Ingrowth core & 10 & 129.2 & Sanford Junior (1990) \\
\hline $\begin{array}{l}\text { Amazonian Tropical Forest } \\
\left(\text { gap }=85 \mathrm{~m}^{2}\right)\end{array}$ & San Carlos, Venezuela & $<2$ & Ingrowth core & 10 & 166.5 & Sanford Junior (1990) \\
\hline $\begin{array}{l}\text { Amazonian Tropical Forest } \\
\left(\text { gap }=126 \mathrm{~m}^{2}\right)\end{array}$ & San Carlos, Venezuela & $<2$ & Ingrowth core & 10 & 95.7 & Sanford Junior (1990) \\
\hline $\begin{array}{l}\text { Amazonian Tropical Forest } \\
\left(\text { gap }=164 \mathrm{~m}^{2}\right)\end{array}$ & San Carlos, Venezuela & $<2$ & Ingrowth core & 10 & 112.6 & Sanford Junior (1990) \\
\hline $\begin{array}{l}\text { Amazonian Tropical Forest } \\
\text { (sandy soil) }\end{array}$ & $\begin{array}{c}\text { Floresta Nacional do Tapajós, } \\
\text { Pará, Brazil }\end{array}$ & $\leq 2$ & Sequential core & 10 & 201.5 & Silver et al. (2005) \\
\hline $\begin{array}{l}\text { Amazonian Tropical Forest } \\
\text { (clay soil) }\end{array}$ & $\begin{array}{l}\text { Floresta Nacional do Tapajós, } \\
\text { Pará, Brazil }\end{array}$ & $\leq 2$ & Sequential core & 10 & 180.5 & Silver et al. (2005) \\
\hline $\begin{array}{l}\text { Eastern Amazonian forest } \\
\text { regrowth (10 years old) }\end{array}$ & Castanhal, Pará, Brazil & $\leq 2$ & Ingrowth core & 10 & $90.6^{b}$ & Present study \\
\hline $\begin{array}{l}\text { Eastern Amazonian forest } \\
\text { regrowth (18 years old) }\end{array}$ & Castanhal, Pará, Brazil & $\leq 2$ & Ingrowth core & 10 & $87.7^{\mathrm{b}}$ & Present study \\
\hline $\begin{array}{l}\text { Eastern Amazonian forest } \\
\text { regrowth (irrigated plots) }\end{array}$ & Castanhal, Pará, Brazil & $\leq 2$ & Ingrowth core & 10 & $94.9^{\mathrm{b}}$ & Lima et al. (2010) \\
\hline $\begin{array}{l}\text { Eastern Amazonian forest } \\
\text { regrowth (litter removal plots) }\end{array}$ & Castanhal, Pará, Brazil & $\leq 2$ & Ingrowth core & 10 & $52.3^{\mathrm{b}}$ & Lima et al. (2010) \\
\hline Deciduous tropical forest & Kodayar, South India & $\leq 2$ & Ingrowth pit & 25 & 262.1 & $\begin{array}{l}\text { Sundarapandian and } \\
\text { Swamy (1996) }\end{array}$ \\
\hline Semi-evergreen forest & Kodayar, South India & $\leq 2$ & Ingrowth pit & 25 & 185.9 & $\begin{array}{l}\text { Sundarapandian and } \\
\text { Swamy (1996) }\end{array}$ \\
\hline $\begin{array}{l}\text { Semi-deciduous Tropical } \\
\text { forest (irrigated plots) }\end{array}$ & Barro Colorado Island, Panamá & $<2$ & Ingrowth core & 25 & 352 & Cavelier et al. (1999) \\
\hline $\begin{array}{l}\text { Semi-deciduous Tropical } \\
\text { forest (control plots) }\end{array}$ & Barro Colorado Island, Panamá & $<2$ & Ingrowth core & 25 & 432 & Cavelier et al. (1999) \\
\hline Tropical dry forest & LaHuerta, Jalisco, Mexico & $\leq 1$ & Sequential core & 10 & 180.5 & Castellanos et al. (2001) \\
\hline Tropical dry evergreen forest & Marakkanam, Coromandel, India & $\leq 2$ & Ingrowth pit & 10 & 103.6 & Visalakshi (1994) \\
\hline Tropical dry evergreen forest & $\begin{array}{l}\text { Puthupet, Sacred Grove, } \\
\text { Coromandel, India }\end{array}$ & $\leq 2$ & Ingrowth pit & 10 & 117.1 & Visalakshi (1994) \\
\hline
\end{tabular}

a Table adapted from Lima (2008)

b Production was calculated by adding the live and dead fine roots production. 
Rainfall seasonality also influenced root mortality, that was greater in the dry than in the wet season at the two sites studied. This growth pattern was also reported by other authors for tropical forests (Sundarapandian and Swamy 1996; Silver et al. 2005). Greater fine-root mortality in the dry period may be associated with the reduction in available water in the soil (Eissenstat et al. 2000; Green et al. 2005). Furthermore, because nutrient availability in the soil is lower during the dry season than in the wet season (Rangel Vasconcelos et al. 2005), the plants must invest more in young fine-root production, whose nutrient absorption capacity is greater than the older roots (Blair and Perfecto 2001).

The lower dead fine-root production at the 18-year-old site was probably due to the wetter microclimate promoted by the greater quantity of litter as suggested by Visalakshi (1994). Between the sites studied (FS10 and FS18), Rangel Vasconcelos et al. (2005) showed a greater quantity of organic matter in the soil at the older site.

The SRL values reported in this study for the two sites were greater than those detected by Jackson et al. (1997) in forest ecosystems $\left(12.2 \mathrm{~m} \mathrm{~g}^{-1}\right)$ and those found by Metcalfe $e t$ al. (2008) in the Amazon tropical forest in sandy $\left(10 \mathrm{~m} \mathrm{~g}^{-1}\right)$ and clay $\left(9 \mathrm{~m} \mathrm{~g}^{-1}\right)$ soils. The greater SRL during the dry season supports the hypothesis presented by Metcalfe et al. (2008) that the plants respond to drought by increasing SRL. This strategy is an advantage for plants that increase their water and nutrient absorption potential. Differences between sites may be a reflection of the quantity of organic matter in the soil, since it was greater in the 18 -year-old site preserved and probably the soil moisture better during the dry season. Data for SRL that give an idea of root morphology are needed to determine how root systems vary among ecosystems and respond to environmental changes (Metcalfe et al. 2008).

In summary, fine-root production in this study was probably limited by water availability in the soil associated with the rainfall season. Fine-root production was not influenced by the chronosequence of the sites studied, which suggests that fine-root production may have already stabilized in the sites or fine root production depended more on climate and soil conditions. Production of mass and length of live fineroots showed in general the same variation pattern. Taking into consideration the difficulties of measuring fine-root production (Jordan and Escalante 1980; Norby et al. 2004), especially using length measurements, mass may be preferred as an indicator of fine-root-production.

\section{ACKNOWLEDGEMENTS}

This work was supported by Brazilian National Council of Technologic and Scientific Development (CNPq, No 475344/2003-0, Project Manipulação de água e nutrientes em ecossistemas de florestas secundárias na Amazônia Oriental). The Deutscher Akademischer Austausch Dienst (DAAD) provided a scholarship to Tâmara Thaiz Santana Lima. We are grateful to Sr. Raimundo Nonato (UFRA) for logistical support, Paulo Alencar and the students Bruno Matos, Fábio Leão, Heraldo Costa, Herison Alves e Magno Reis for their help in fields sampling.

\section{REFERENCES}

Aerts, R.; Bakker, C.; Caluwe, H. 1992. Root turnover as determinant of the cycling of $\mathrm{C}, \mathrm{N}$ and $\mathrm{P}$ in a dry heathland ecosystem. Biochemistry, 15: 175-190.

Araújo, M.M.A.; Tucker, J.M.; Vasconcelos, S.S.; Zarin, D.J.; Oliveira, W.; Sampaio, P.D.; Rangel-Vasconcelos, L.G.; Oliveira, F.A.; Coelho, R.FR.; Aragão, D.V.; Miranda, I. 2005. Successional pattern and process in secondary forests of different ages in the eastern amazon. Ciência Florestal, 15: 343-357 (in Portuguese, with abstract in English).

Blair, B.C.; Perfecto, I. 2001. Nutrient content and substrate effect on fine root density and size distribution in a Nicaraguan Rain Forest. Biotropica, 33: 697-701.

Cairns, M.A.; Brown, S.; Helmer, E.H.; Baumgardner, G.A. 1997. Root biomass allocation in the world's upland forests. Oecologia, 111:1-11.

Castellanos, J.; Jaramillo, V.J.; Sanford, R.L.; Kauffman, J.B. 2001. Slash-and-burn effects on fine root biomass and productivity in a tropical dry forest ecosystem in México. Forest Ecology and Management, 148:41-50.

Cavelier, J.; Estevez, J.; Arjona, B. 1996. Fine-root biomass in three sucessional stages of an Andean cloud forest in Colombia. Biotropica, 28: 728-736.

Cavelier, J.; Wright, S.J.; Santamaría, J. 1999. Effects of irrigation on litterfall, fine root biomass and production in a semideciduos lowland forest in Panama. Plant and Soil, 211:207-213.

Coelho, R.F.R.; Zarin, D.J.; Miranda, I.S.; Tucker, J.M. 2003. Floristc composition and structure of a forest in different successional stages in Castanhal, Pará. Acta Amazonica, 33: 563 582 (in Portuguese, with abstract in English).

Cuevas, E.; Medina, E. 1988. Nutrient dynamics within amazonian forests. II. Fine root growth, nutrient availability and leaf litter decomposition. Oecologia, 76: 222-235.

Dowdy, R.H.; Nater, E.A.; Dolan, M.S. 1995. Quantification of the length and diameter of root segments with public domain software. Communication in Soil Science and Plant Analysis, 26: $459-468$.

Eissenstat, D.M.; Wells, C.E.; Yanai, R.D. Whitbeck, J.L. 2000. Building roots in a changing environment: implications for root longevity. New Phytologist. 147: 33-42.

Feldpausch, T.R.; Rondon, M.A.; Fernandes, C.M.; Riha, S.J.; Wandelli, E. 2004. Carbon and nutrient accumation in secondary forests regenerating on pastures in central amazonia. Ecological Applications, 14: 164-176. 
Gower, S.I.; Vitousek, P.M. 1989. Effects of nutrient amendments on fine root biomass in a primary successional forest in Hawaii. Oecologia, 81: 566-568.

Gower, S.T. 1987. Relations between mineral nutrient availability and fine root biomass in two Costa Rican tropical wet forests: A hypothesis. Biotropica, 19: 171-175.

Green, J.J.; Dawson, L.A.; Proctor, J.; Duff, E.I.; Elston, D.A. 2005. Fine root dynamics in a tropical rain forest is influenced by rainfall. Plant and Soil, 276: 23-32.

Hendrick, R.L.; Pregitzer, K.S. 1996. Temporal and depth related patterns of the fine root dynamics in northern hardwood forests. Journal of Ecology, 84:167-176.

Hook, P.B.; Lauenroth, W.K.; Burke, I.C. 1994. Spatial patterns of roots in a semiarid grassland:abundance of canopy openings and regeneration gaps. Journal of Ecology, 82: 485-404.

Hughes, R.F.; Kauffman, J.B.; Jaramillo, V.J. 1999. Biomass, carbon, and nutrient dynamics of secondary forests in a humid tropical region of Mexico. Ecology, 80: 1892-1907.

Jackson, R.B.; Mooney, H.A.; Schulze, E.D. 1997. A global budget for fine root biomass, surface area, and nutrient contents. Proceedings of the National Academy of Sciences, 94:7362-7366.

Jaramillo, V.J.; Ahedo-Hérnandez, R.; Kauffman, J.B. 2003. Root biomass and carbon in a tropical evergreen forest of Mexico: changes with secondary succession and forest conversion to pasture. Journal of Tropical Ecology, 19: 457-464.

Jordan, C.F.; Escalante, G. 1980. Root productivity in a Amazonian Rain Forest. Ecology, 61: 14-18.

Jorge, L.A.C. 1996. Recomendaçôes práticas para aquisição de imagens digitais através do SIARCS. Recomendação Técnica, 96: 56.

Jorge, L.A.C.; Crestana, S. 1996. Recomendaçóes práticas para utilizaçáo do SIARCS 3.0 nos estudos de raízes, cobertura vegetal, folhas e outras aplicações. Recomendação Técnica, 96: 21.

Joslin, J.D.; Wolfe, M.H.; Hanson, P.J. 2000. Effects of altered water regimes on forest root systems. New Phytologist, 147: 117-129.

Kätterer, T.A; Fabiao, M; Madeira, C; Ribeiro; E. Steen. 1995. Fine-root dynamics, soil moisture and soil carbon content in a Eucalyptus globulus plantation under different irrigation and fertilisation regimes. Forest Ecology and Management, 74: 1-12.

Kavanagh, T.; Kellman, M. 1992. Seasonal pattern of fine root proliferation in a tropical dry forest. Biotropica, 24: 157-165.

Lima, T.T.S. 2008. Production of fine roots in a secondary forest of eastern Amazonia. Dissertação de Mestrado, Universidade Federal Rural da Amazônia, Belém, Pará. 56 pp (in Portuguese).

Lima, T.T.S.; Miranda, I.S.; Vasconcelos, S.S. 2010. Effects of water and nutrient availability on fine root growth in eastern Amazonian forest regrowth, Brazil. New Phytologist, 187:622-630.

Lima, A.J.N.; Teixeira, L.M.; Carneio, M.C.; Santos, J.; Higuchi, N. 2007. Biomass stock and structural analysis of a secondary forest in Manaus (AM) region, ten years after clear cutting followed by fire. Acta Amazonica, 37:49-54 (in Portuguese, with abstract in English).
Lima Filho, D.A.; Revilla, J.; Coêlho, L.S.; Ramos, J.F.; Santos, J.L.; Oliveira, J.G. 2002. Natural Regeneration of Tree Hectares of "Terra Firme" Forest in the Petroleum Drilling Region of the Urucu River in the Amazon State, Brazil. Acta Amazonica, 32: 555-569 (in Portuguese, with abstract in English).

Lu D, Mausel P, Brondízio E, Moran E 2003. Classification of succesional forest stages in the Brazilian Amazzon basin. Forest Ecology and Management, 181: 301-312.

Makkonen, K.; Helmisaari, H. 1999. Assessing fine-root biomass and production in a Scots pine stand-comparison of soil core and root ingrowth core methods. Plant and Soil, 210: 43-50.

Martorano, L.G.; Pereira, L.C. 1993. Estudos climáticos do Estado do Pará, classificação climática (Köppen) e deficiência hídrica (Thornthwaite, Mater). Belém, Brazil: SUDAM/EMBRAPASNLCS.

Maycok, C.R.; Congdon, R.A. 2000. Fine root biomass and soil N and $\mathrm{P}$ in north queensland rain forest. Biotropica, 32: 185-190.

Metcalfe, D.B.; Meir, P.; Aragão, L.E.O.C.; Costa, A.C.L.; Braga, A.P.; Gonçalves, P.H.L.; Silva Junior, J.A.; Almeida, S.S.; Dawson, L.A.; Malhi, Y.; Williams, M. 2008. The effects of water availability on root growth and morphology in an Amazon rainforest. Plant and Soil, 311:189-199.

McClaugherty, C.A.; Aber, J.D.; Melillo, J.M. 1982. The role of fine roots in the organic matter and nitrogen budgets of two forested ecosystems. Ecology, 63: 1481-1490.

McGroddy, M.; Silver, W.L. 2000. Variations in belowground carbon storage and soil $\mathrm{CO}_{2}$ flux rates along a wet tropical climate gradient. Biotropica, 32: 614-624.

Nelson, B.W.; Mesquita, R.; Pereira, J.L.G.; Souza, S.G;A.; Batista, G.T.; Couto, L.B. 1999. Allometric regressions for improved estimate of secondary forest biomass in the central Amazon. Forest Ecology and Management, 117: 149-167.

Norby, R.J.; Ledford, J.; Relly, C.D.; Miller, N.E.; O’Neill, E.G. 2004. Fine-root production dominates response of a deciduous forest to atmospheric $\mathrm{CO}_{2}$ enrichment. Proceedings of the National Academy of Sciences, 101: 9689-9693.

Pregitzer, K.S; King, J.S; Burton, A.J; Brown, S.E. 2000. Responses of tree fine roots to temperature. New Phytologist, 147: 105-115.

Rangel-Vasconcelos, L.G.T.; Zarin, D.J; Carvalho, C.J.R.; Del Santos, M.M.; Vasconcelos, S.S.; Oliveira, F.A. 2005. Carbon and nitrogen of soil microbial biomass and microbial respiration of secondary vegetation in eastern Amazonia. Revista de Ciências Agrárias, 44: 49-63(in Portuguese, with abstract in English).

Rodrigues, M.A.C.M.; Miranda, I.S.; Kato, M.S.A. 2007a. Structure of secondary forests after two different systems of land use in the northeastern Pará state, Brazil. Acta Amazonica, 37: $591-598$ (in Portuguese, with abstract in English).

Rodrigues, M.A.C.M.; Miranda, I.S.; Kato, M.S.A. 2007b. Flora and structure of the secondary vegetation after the use of different crushers. Pesquisa Agropecuária Brasileira, 42: 459-465 (in Portuguese, with abstract in English).

Sanford, R.L. 1990. Fine root biomass under light gap openings in an Amazon rain forest. Oecologia, 83: 541-545. 
Silver, W.L.; Thompson, A.W.; McGroddy, M.E.; Varner, R.K.; Dias, J.D.; Silva, H.; Crill, P.M.; Keller, M. 2005. Fine root dynamics and trace gas fluxes in two lowland tropical forests soils. Global Change Biology, 11: 290-306.

Smith, J.; Ferreira, S.; Van De Kop, P.; Ferreira, C.P.; Sabogal, C. 2003. The persistence of secondary forests on colonist farms in the Brazilian Amazon. Agroforestry Systems, 58: 125-135.

Steininger, M.K. 2000. Secondary forest structure and biomass following short and extended land-use in central and southern Amazonia. Journal of Tropical Ecology, 16: 689-708.

Stewart, C.G. 2000. A test of nutrient limitation in two tropical montane forests using root ingrowth cores. Biotropica, 32: 369-373.

Sundarapandian, S.M.; Swamy, P.S. 1996. Fine root biomass distribution and productivity patterns under open and closed canopies of tropical forest ecosystems at Kodayar in Western Ghats, South India. Forest Ecology and Management, 86: 181-192.

Tenório, A.R.D.M.; Graça, J.J.D.C.; Góes, J.E.M.; Mendez, J.G.R.; Gama, J.R.M.F.; Silva, P.R.O.D.; Chagas, P.S.M.D.; Silva, R.N.P.D.; Américo, R.R.; Pereira, W.L.M. 1999. Mapeamento dos solos da estação de piscicultura de Castanhal, PA. FCAP Informe Técnico, 25: 5-26.

Tucker, J.M.; Brondizio, E.S.; Morán, E.F. 1998. Rates of forest regrowth in eastern Amazônia: a comparison of Altamira and Bragantina regions, Pará state, Brazil. Interciencia, 23: 64-73.

Valverde-Barrantes, O.J.; Raich, J.W.; Russell, A.E. 2007. Fine-root mass, growth and nitrogen content for six tropical tree species. Plant and Soil, 290: 357-370.

Vasconcelos, S,S.; Zarin, D.J.; Capanu, M.; Littell, R.; Davidson, E.A.; Ishida, F.Y.; Santos, E.B.; Araújo, M.M.; Aragão, D.V.; Rangel-Vasconcelos, L.G.T.; Oliveira, F.A.; McDowell, W.H.; Carvalho, C.J.R. 2004. Moisture and substrate availability constrain soil trace gas fluxes in an eastern Amazonian regrowth forest. Global Biogeochemical Cycles, 18: GB2009, doi: 2010.1029/2003GB002210.
Vasconcelos, S.S.; Zarin, D.J.; Araújo, M.M.; Rangel-Vasconcelos, L.G.T., Carvalho, C.J.R.; Staudhammer, C.L.; Oliveira, F.A. 2008. Effects of seasonality, litter removal and dry-season irrigation on litterfall quantity and quality in eastern Amazonian forest regeowth, Brazil. Journal of Tropical Ecology, 24: 27-38.

Vieira, G.; Hosokawa, R.T. 1989. Composição florística da vegetação da regeneração natural. 1 ano após diferentes níveis de exploração de uma floresta úmida. Acta Amazonica, 19: 401-413.

Vieira, I.C.G.; Almeida, A.S.; Davidson, E.A.; Stone, T.A.; Carvalho, C.J.R.; Guerreiro, J.B. 2003. Classifying successional forests using Landsat spectral properties and ecological characteristics in eastern Amazônia. Remote Sensing of Environment, 87: 470-481.

Vieira, I.C.G.; Toledo, P.M.; Almeida, A.s. 2007. Análise das modificaçóes da paisagem da regiấo bragantina, no Pará, integrando diferentes escalas de tempo. Ciência e Cultura, 59: 27-30.

Visalakshi, N. 1994. Fine root dynamics in two tropical dry evergreen forests in sourthern India. Journal of Biosciences, 19: 103-116.

Vogt, K.A.; Vogt, D.J.; Bloomfield, J. 1998. Analysis of some direct and indirect methods for estimating root biomass and production of forests at an ecosystem level. Plant and Soil, 200: 71-89.

Vogt, K.A.; Vogt, D.J.; Palmiotto, P.A.; Boon, P.; O’Hara, J.; Asbjornsen, H. 1996. Review of root dynamics in forest ecosystems grouped by climate, climatic forest type and species. Plant and Soil, 187: 159-219.

Yavitt, J.B.; Wright, S.J. 2001. Drought and irrigation effects on fine root dynamics in a tropical moist forest, Panama. Biotropica, 33: 421-434.

Zangaro, W.; Nishidate, F.R.; Vandresen, J.; Andrade, G.; Nogueira, M.A. 2007. Root mycorrhizal colonization and plant responsiveness are related to root plasticity, soil fertility and sucessional status of native woody species in southern Brazil. Journal of Tropical Ecology, 23: 53-62.

Recebido 07/12/2010

Aceito 01/04/2011 
